\title{
Digestibility and feeding behavior of cattle fed soybean hulls to replace corn in high concentrate diets ${ }^{1}$
}

\section{Digestibilidade e comportamento ingestivo de bovinos alimentados com níveis casca de soja em substituição ao milho em dietas de alta proporção de concentrado}

\author{
Pedro Leonardo de Paula Rezende ${ }^{2 *}$; João Restle ${ }^{3}$; Ubirajara Oliveira Bilego ${ }^{2}$; \\ Juliano José de Resende Fernandes ${ }^{3}$; Regis Luis Missio ${ }^{4}$; \\ Rayane Galdino Menezes²; Tiago Pereira Guimarães ${ }^{2}$
}

\begin{abstract}
The objective of this study was to evaluate the replacement of $0,25,50,75$ and $100 \%$ of ground corn (GC) with pelleted soybean hulls (SH) in the concentrate portion of cattle diets. The evaluation was conducted using five 13-month-old Nellore steers cannulated in the rumen, with a mean body weight of $265.00 \pm 11.60 \mathrm{~kg}$. The steers received a diet composed of $90 \%$ concentrate and $10 \%$ sugarcane bagasse as the only source of roughage. The statistical design used was a $5 \times 5$ Latin square. There was no effect $(p>0.05)$ of replacement levels or interaction $(p>0.05)$ between replacement levels and sampling time on ruminal $\mathrm{pH}$, which ranged from 5.8 to 6.0. The apparent digestibility of DM, CP, EE, CHOT and CHONF were not influenced $(\mathrm{p}>0.05)$ by the replacement levels, showing mean values of 67.88 $\pm 2.02 ; 67.43 \pm 2.89 ; 68.29 \pm 4.11 ; 70.54 \pm 1.68$ and $80.21 \pm 1.85 \%$, respectively. The NDF digestibility increased linearly $(\mathrm{p}<0.05)$ with the replacement of corn with soybean hulls. There was no effect $(\mathrm{p}$ $>0.05)$ of replacement levels on time spent feeding (F) and total idle time (TI), with mean values of 10.51 and $4.61 \%$ of the day, respectively. However there was a quadratic effect $(\mathrm{p}<0.05)$ of soybean hull inclusion on the time spent ruminating. It was concluded that although the replacement of corn with soybean hull does not improve the ruminal $\mathrm{pH}$ of steers fed diets with a high proportion of concentrate, pelleted soybean hulls improve the digestibility of the fibrous fraction of the diet and increase the time spent ruminating, indicating that this ingredient can be included in high-concentrate diets to improve economic efficiency.
\end{abstract}

Key words: Byproducts. Effective fiber. Ruminal parameters. Pectin. Starch.

\section{Resumo}

Objetivou-se com este estudo avaliar a substituição de $0,25,50,75$ e 100\% do milho moído (GC) por casca do grão de soja peletizada (SH) na porção concentrada da dieta de novilhos confinados, alimentados com dietas de alta proporção de concentrado. Os animais foram alimentados com dietas constituídas por $90 \%$ de concentrado e $10 \%$ de bagaço de cana como única fonte de volumoso. O delineamento utilizado foi em quadrado latino $5 \mathrm{x} 5$ no qual foram utilizados 5 novilhos da raça Nelore,

${ }^{1}$ Parte da tese de doutorado do primeiro autor.

2 Discentes, Programa de Pós-Graduação em Ciência Animal, Universidade Federal de Goiás, UFG, Goiânia, GO, Brasil. E-mail: pedrozootec@hotmail.com; birabilego@hotmail.com; rayannegaldino@zootecnista.com.br; tiagopereirarv@hotmail.com

3 Profs. Drs, Departamento de Zootecnia, UFG, Goiânia, GO, Brasil. E-mail: julianojrf@gmail.com; jorestle@terra.com.br

4 Prof. Dr, Departamento de Ciências Agrárias, Universidade Tecnológica Federal do Paraná, UTFPR, Pato Branco, PR, Brasil. E-mail: regisluismissio@gmail.com

* Author for correspondence 
canulados no rumen, com peso vivo médio de $265,00 \pm 11,60 \mathrm{~kg}$ e 13 meses de idade. Não houve efeito $(\mathrm{P}>0,05)$ dos tratamentos ou interação $(\mathrm{P}>0,05)$ entre tratamento e tempo de coleta sobre o $\mathrm{pH}$ do líquido ruminal. As médias finais constatadas entre os tratamentos variaram de 5,8-6,0. As digestibilidades aparentes da MS, PB, EE, CHOT e CHONF não foram influenciadas $(\mathrm{P}>0,05)$ pelos tratamentos, apresentando valores médios de 67,$88 ; 67,43 ; 68,29 ; 70,54$ e $80,21 \%$, respectivamente, entretanto a digestibilidade da FDN aumentou $(\mathrm{p}<0,05)$ linearmente conforme aumentou a inclusão de SH em substituição ao GC. Não houve efeito $(\mathrm{P}>0,05)$ dos tratamentos sobre tempo despendido com alimentação (F) e ócio total (TI), apresentando valores médios de 10,51 e 4,61\% do dia, respectivamente. Constatou-se efeito quadrático $(\mathrm{p}<0,05)$ dos níveis de inclusão de SH em substituição ao GC sobre o tempo despendido com ruminação. Concluiu-se que, apesar da substituição do milho pela casca de soja não promover a melhoria do $\mathrm{pH}$ ruminal de novilhos alimentados com dietas com alta proporção de concentrado, as características da casca de soja peletizada proporcionam maior digestibilidade da fração fibrosa da dieta e maior tempo desprendido com ruminação, quando ocorre a substituição total do GC por SH, indicando que este ingrediente pode ser incluído em dietas de alta proporção de concentrado com objetivo de melhorar a ruminação e o aproveitamento da fração fibrosa da dieta, proporcionando eficiencia economica.

Palavras-chave: Amido. Coprodutos. Fibra efetiva. Parâmetros ruminais. Pectina.

\section{Introduction}

Alternative energy sources can be included in feedlot cattle diet to reduce feed costs through total or partial substitution of corn with ingredients with desirable economic and nutritional characteristics. Soybean hulls are considered a potential substitute for ground corn in feedlot diets (EZEQUIEL et al., 2006). Soybean hulls are characterized by a high content of potentially digestible fiber that according to Ludden et al. (1995) is equivalent to approximately $74-80 \%$ of the energy value of corn grain, when included in high-concentrate diets fed to feedlot steers.

The use of cereals rich in starch such as corn and sorghum in cattle diet may need to be restricted as they increase the production of volatile fatty acids in the rumen, leading to lactate accumulation, and a fall in ruminal $\mathrm{pH}$ that prejudices fiber digestion, with a negative impact on production costs. In addition, economic losses may occur due to acute acidosis and death of the animals (IPHARRAGUERRE; CLARK, 2003). Corn grain is the most commonly used ingredient to meet the energy requirements of animals. But when used in large quantities, it can reduce the digestibility of the fiber fraction of the diet due to the reduction of ruminal pH (HOOVER, 1986).
According to Fischer and Mülhbach (1999) the more favorable ruminal environment for the development of fibrolytic bacteria that arises when animals are fed soybean hulls as an energy source may be related to the lower negative associative effect of this component on the digestibility of the fibrous fraction of the diet due to decreased production of lactic acid, resulting in a less drastic effect on the $\mathrm{pH}$. This is likely to be the main reason why studies do not usually detect differences in the performance of animals fed corn or soybean hulls in high roughage diets (EZEQUIEL et al., 2006). The same hypothesis is supported by Freitas et al. (2013), who studied the performance of finishing steers fed different sources of carbohydrates. The authors concluded that soybean hulls can completely replace corn in diets containing approximately $60 \%$ concentrate for steers in the finishing phase without affecting dry matter intake and mean daily gain, while also leading to an improvement in feed conversion.

Wing (1982) reviewed several experiments and found that the ratio between volatile fatty acids produced in the rumen during the fermentation of soybean hulls determined the higher ruminal $\mathrm{pH}$, with higher acetic acid production compared to the fermentation of starchy ingredients. However, most research evaluating the use of soybean hulls 
as a substitute for corn was conducted with low- to moderate-concentrate diets (RESTLE et al., 2004; MENDES et al., 2005; EZEQUIEL et al., 2006). Thus the potential for using this ingredient in highconcentrate diets remains unknown. The objective of this study was to evaluate the effects of partial or total replacement of ground corn with soybean hulls on the digestibility and ingestive behavior of confined steers fed high-concentrate diets.

\section{Material and Methods}

The experiment was conducted in experimental feedlot beef cattle at the School of Veterinary Medicine and Animal Science, Federal University of Goiás, Goiânia, in the period July to September 2012. The design was a 5x5 Latin square involving five 13-month-old Nelore steers, cannulated in the rumen, with a mean body weight of $265.00 \pm 11.60$ $\mathrm{kg}$. The experimental protocol was approved by the ethics committee for the use of animals in scientific experiments of the Federal University of Goiás, according to protocol $\mathrm{N}^{\circ}$. 076/15.

The animals were kept in individual stalls partially covered with concrete floor and fed daily, at 8:00 and 18:00 h. The study was divided into five experimental periods of 13 days each, comprising 10 days of adaptation to the diets and 3 days of data collection. The treatments consisted of five levels $(0,25,50,75$ and $100 \%)$ of replacement of ground corn (GC) with pelletd soybean hulls (SH) in the concentrate portion of the diet, which comprised $90 \%$ concentrate and $10 \%$ sugarcane bagasse as the only source of forage. Diets were formulated with the aim of achieving protein equivalence. The concentrate was composed of ground corn and/or pelleted soybean hulls, soybean meal and mineral mixture as described in Table 1.

Table 1. Bromatological composition and ingredients (\%) of experimental diets based on dry matter (DM).

\begin{tabular}{lccccc}
\hline \multirow{2}{*}{ Nutrients, \% } & \multicolumn{5}{c}{ Soybean hull levels, \% } \\
\cline { 2 - 6 } & $00^{1}$ & $25^{2}$ & $50^{3}$ & $75^{4}$ & $100^{5}$ \\
\hline $\mathrm{CP}$ & 15.12 & 15.54 & 16.41 & 17.89 & 16.10 \\
$\mathrm{NDF}$ & 27.42 & 32.09 & 38.31 & 50.12 & 56.50 \\
$\mathrm{ADF}$ & 9.64 & 15.12 & 20.27 & 30.96 & 36.67 \\
$\mathrm{EE}$ & 2.50 & 2.35 & 1.98 & 1.65 & 1.38 \\
$\mathrm{MM}$ & 9.23 & 6.82 & 7.51 & 7.28 & 6.29 \\
$\mathrm{CHONF}$ & 45.71 & 43.18 & 35.76 & 23.04 & 19.72 \\
CHOT & 73.13 & 75.28 & 74.07 & 73.16 & 76.22 \\
\hline & & \multicolumn{3}{c}{} \\
\hline Sugarcane bagasse & 10.00 & 10.00 & Ingredients \% DM & 10.00 \\
Soybean meal & 12.99 & 12.65 & 10.00 & 10.00 & 12.43 \\
Ground corn & 73.28 & 53.55 & 35.49 & 12.42 & 0.00 \\
Soybean hulls & 0.00 & 20.24 & 38.72 & 17.52 & 74.07 \\
Mineral mixed $^{*}$ & 3.71 & 3.62 & 3.57 & 56.59 & 3.55 \\
\hline
\end{tabular}

$\mathrm{CP}$ - Crude protein; NDF - Neutral detergent fiber; ADF - Acid detergent fiber; EE - Ether extract; MM - Mineral matter; CHONF - Non-structural carbohydrate; CHOT - Total carbohydrate; 1 - 100\% Ground corn; 2 - 25\% replacement of corn with soybean hull; $3-50 \%$ replacement of corn with soybean hull; $4-75 \%$ replacement of corn with soybean hull; 5 - $100 \%$ soybean hull; *Phosphate: $13.56 \%$; Calcite: 50.53\%; Micro-mineral: 9.86\%; White salt: 24.65\%; Virginiamycin: $0.81 \%$; Ionophore: $0.59 \%$. 
Ruminal fluid samples were collected for $\mathrm{pH}$ evaluation on day 1 of each collection period, immediately before the first supply of food $(8: 00 \mathrm{~h})$ and then after every 2 hours, obtaining samples at the following collection times: $0,2,4,6$ and 8 hours post-feeding. In an attempt to achieve homogeneity of the samples, the rumen fluid was collected at four different points in the rumen. The $\mathrm{pH}$ measurements were made immediately after collection using a $\mathrm{pH}$ meter (Model 290A digital meter, Beverly, MA).

To evaluate the apparent digestibility of the diet we collected samples of the food offered and the uneaten food (remains) and also sampled feces collected directly from the rectum of animals on the 3 days of collection to obtain a composite sample. The dry matter in the feces was estimated using the internal indicator technique (COCHRAN et al., 1986), adopting the indigestible neutral detergent fiber (NDFi) as an indicator. The NDFi contents of feces samples, food offered and the remains were obtained after in situ incubation in the rumen for 240 hours as described by Casali et al. (2008). Fecal production (FP) was estimated using the formula: FP $(\mathrm{kg} / \mathrm{DM} /$ day $)=\left(\right.$ consumption $\mathrm{NDFi} /{ }^{\circ} \mathrm{NDFi}$ in feces)*100. The apparent digestibility (AD) of the $\mathrm{DM}$ and nutrients was calculated using the formula: $\mathrm{AD}(\%)=[($ ingested nutrient - nutrient excreted $) /$ ingested nutrient] x 100 .

The feces samples, food and remains were dried, ground and passed through a 16 mesh sieve $(1 \mathrm{~mm})$ to determine the dry matter, organic matter, crude protein (Kjeldahl method) and ether extract, according to the methodology described in AOAC (1995); neutral detergent fiber (NDF) and acid detergent fiber (ADF) were measured according to the methodology of neutral or acid digestion detergent, respectively, as described by Van Soest (1991). The non-fiber carbohydrates (NFC) were calculated from the equation suggested by Hall (2000) in which: NFC $=100-[(\% \mathrm{CP}-\% \mathrm{CP}$ urea $+\%$ urea $)+$ NDFap $+\%$ EE $+\%$ ash $]$; total carbohydrates (CHOT) were determined from the equation: $\mathrm{CHOT}=100-(\% \mathrm{CP}+\% \mathrm{EE}+\%$ ash $)$.
Visual behavioral evaluations were conducted by trained observers, individually for each animal, on the $3^{\text {rd }}$ day of each collection period. The observation period started at 6:00 am and the observer evaluated the feeding activities, ruminating while lying down, ruminating while standing, idle lying, idle standing and other activities intermittently every 5 minutes for 24 consecutive hours. Artificial lighting was used during the night, to which the animals were previously adapted.

The experimental design was a Latin square with five treatments (diets) and five replicates (animals) in five periods (time-repeated measures), analyzed using the MIXED procedure of the Statistical Analysis System (SAS, 2002). Data were analyzed for normality using the Shapiro-Wilk test and, when necessary, transformed by $\log ^{2}$. When the assumptions for the normality and homogeneity of the variances were satisfied, the data were submitted to analysis of variance and orthogonal contrasts and the differences were evaluated using the Tukey test. The residual effects of the order in which the treatments were applied to the animals were isolated. The maximum level of significance was 0.05 .

The statistical model adopted was represented by: $\gamma \mathrm{ijkl}=\mu+\tau \mathrm{i}+£ \mathrm{j}(\tau \mathrm{i})+\alpha \mathrm{k}+(\tau \alpha) \mathrm{ik}+\varepsilon \mathrm{ijkl}$, where: $\gamma \mathrm{ijkl}=$ dependent variable; $\mu=$ general mean; $\tau i=$ treatment effect $i ; £ j(\tau i)=$ effect of the repetition in treatment $\mathrm{i} ; \alpha \mathrm{k}=$ effect of period $\mathrm{k} ;(\tau \alpha)$ $\mathrm{ik}=$ interaction between treatment $\mathrm{i}$ and period $\mathrm{k}$; eijkl = experimental residual error.

\section{Results and Discussion}

There was no effect $(p>0.05)$ of the replacement levels or interaction $(p>0.05)$ between replacement levels and collection time on the $\mathrm{pH}$ of the rumen fluid. The final mean observed $\mathrm{pH}$ ranged from 5.8 to 6.0 . The $\mathrm{pH}$ of the rumen fluid became significantly more acid after 4 hours post-feeding at all replacement levels, indicating that the peak of lactic acid accumulation in the rumen occurred at a similar time among the diets evaluated, as shown in Table 2. 
Table 2. Mean $\mathrm{pH}$ of the rumen fluid as a function of post-feeding time.

\begin{tabular}{|c|c|c|c|c|c|c|c|}
\hline \multirow{2}{*}{$\begin{array}{c}\text { Collection } \\
\text { time, }{ }^{\text {hs }}\end{array}$} & \multicolumn{5}{|c|}{ Soybean hull levels, \% } & \multirow[b]{2}{*}{ mean } & \multirow[b]{2}{*}{$\mathrm{p}$ value } \\
\hline & $00^{1}$ & $25^{2}$ & $50^{3}$ & $75^{4}$ & $100^{5}$ & & \\
\hline 0 & $6.21 \pm$ & $6.18 \pm$ & $6.10^{ \pm}$ & $6.27 \pm$ & $6.13 \pm$ & $6.18^{ \pm}$ & 0.2519 \\
\hline 2 & $6.16^{ \pm}$ & $6.10 \pm$ & $6.08 \pm$ & $6.22 \pm$ & $6.06 \pm$ & $6.12 \pm$ & 0.3126 \\
\hline 4 & $5.84 \pm$ & $5.76 \pm$ & $5.80^{ \pm}$ & $5.98 \pm$ & $5.85 \pm$ & $5.85 \pm$ & 0.5457 \\
\hline 6 & $5.92 \pm$ & $5.79 \pm$ & $5.61 \pm$ & $5.91 \pm$ & $5.77 \pm$ & $5.80 \pm$ & 0.4393 \\
\hline 8 & $5.90 \pm$ & $5.81 \pm$ & $5.71 \pm$ & $5.92 \pm$ & $5.92 \pm$ & $5.85 \pm$ & 0.3973 \\
\hline mean & $6.01 \pm$ & $5.93 \pm$ & $5.86 \pm$ & $6.06 \pm$ & $5.95 \pm$ & $5.96 \pm$ & 0.3492 \\
\hline
\end{tabular}

$1-100 \%$ corn; $2-25 \%$ replacement of corn with soybean hull; $3-50 \%$ replacement of corn with soybean hull; $4-75 \%$ replacement of corn with soybean hull; $5-100 \%$ soybean hull. Means followed by distinct letters indicate statistical difference detected by the Tukey test at 5\% significance; VC (variation coefficient); p (level of significance); ns (not significant).

The results showed that the possible benefits of replacing starch with digestible fiber on the ruminal environment were not confirmed to the experimental conditions evaluated ( $90 \%$ concentrate). Ludden et al. (1995) studied the effects of replacing corn with soybean hulls in high-concentrate diets for steers and reported an increase in dry matter intake as soybean hull inclusion increased. Thus, although there was a lower rate of degradation of soybean hull in relation to ground corn, the increase in consumption probably resulted in the same VFA accumulation rate as corn when the inclusion of $\mathrm{SH}$ increased. Removal of VFAs from the rumen occurs by passive absorption from the ruminal wall or from passage of the fluid phase to the omasum (TAMMINGA; VAN VUUREN, 1988). Thus, even if $\mathrm{SH}$ fermentation is predominantly acetic, with less accumulation of lactic acid and consequently less propionate, if the production rate exceeds the removal rate, the accumulation of large amounts of total VFAs in the rumen may lead to a reduction in $\mathrm{pH}$ in the treatments with higher amounts of $\mathrm{SH}$, as shown in Figure 1.

The results obtained in this study are consistent with those described by Orr et al. (2008). They studied the substitution of GC with $\mathrm{SH}$ and its effects on the digestibility of forage-based diets in confined steers, and found no effect of the replacement levels on the $\mathrm{pH}$ of ruminal liquid, which varied from 6.0 to 6.8. Different results were reported by Nguyen et al. (2008), who evaluated the effects of supplementation with GC or SH in steers fed hay diets. They reported an increase in the total production of VFA and in the molar proportion of propionate that led to a reduction in ruminal $\mathrm{pH}$ when the animals were supplemented with corn. These divergent results could be attributed to the higher level of consumption of concentrated foods used in the present study (90\%).

The apparent digestibilities of DM, CP, EE, CHOT and CHONF were not influenced by the replacement levels ( $\mathrm{p}>0.05)$, with mean values of $67.88,67.43,68.29,70.54$ and $80.21 \%$, respectively; however the digestibility of NDF increased $(p<0.05)$ linearly with the inclusion of $\mathrm{SH}$, probably due to the higher amounts of this component in the diets with more SH. Despite the linear increase in the apparent digestibility of NDF, this effect was not sufficient to result in a significant increase in DM intake, which ranged from 6.2 to $6.7 \mathrm{~kg} \mathrm{DM} /$ day (Table 3). 
Figure 1. Graphical representation of the $\mathrm{pH}$ curve of the ruminal liquid as a function of post-feeding time

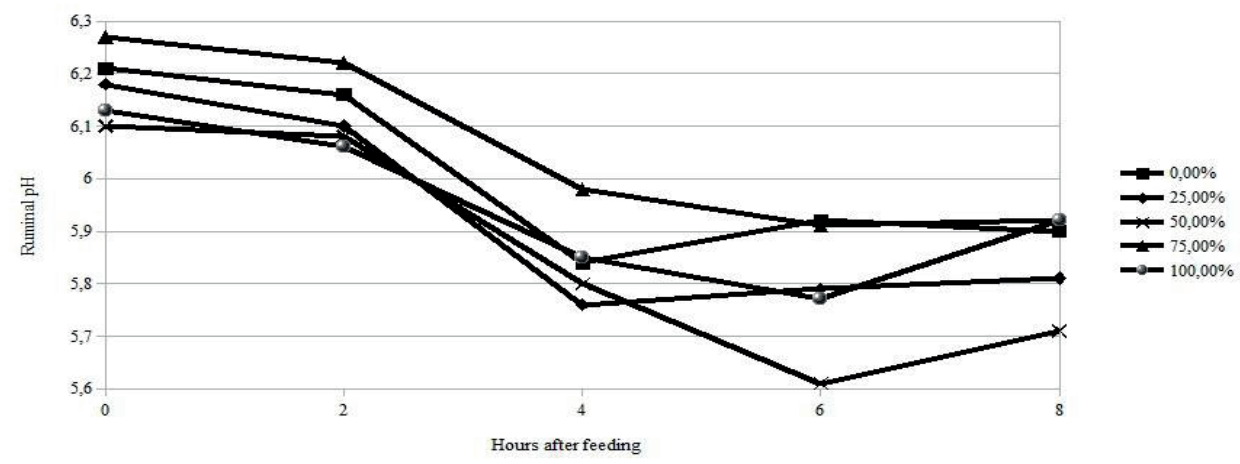

Table 3. Means and standard error of dry matter intake and apparent digestibility coefficients of DM and nutrients.

\begin{tabular}{lccccccc}
\hline & \multicolumn{9}{c}{ Soybean hull levels, \% } & \multicolumn{3}{c}{ Contrasts } \\
\cline { 2 - 8 } & 0 & 25 & 50 & 75 & 100 & $\mathrm{~L}$ & $\mathrm{Q}$ \\
\hline DMI, ${ }^{\mathrm{kg} / \text { day }}$ & $6.29 \pm 0.52$ & $6.29 \pm 0.52$ & $6.55 \pm 0,52$ & $6.50 \pm 0.52$ & $6.72 \pm 0.52$ & 0.492 & 0.951 \\
DDM. \% & $66.07 \pm 2.02$ & $69.02 \pm 2.02$ & $66.65 \pm 2.02$ & $72.18 \pm 2.02$ & $65.48 \pm 2.02$ & 0.863 & 0.412 \\
DCP. \% & $65.12 \pm 2.89$ & $68.74 \pm 2.89$ & $66.47 \pm 2.89$ & $73.23 \pm 2.89$ & $63.63 \pm 2.89$ & 0.904 & 0.245 \\
DEE. \% & $70.21 \pm 4.11$ & $72.54 \pm 4.11$ & $71.23 \pm 4.11$ & $75.87 \pm 4.11$ & $58.58 \pm 4.11$ & 0.303 & 0.139 \\
DNDF. \% & $51.65 \pm 1.85$ & $55.76 \pm 1.85$ & $60.25 \pm 1.85$ & $70.24 \pm 1.85$ & $66.18 \pm 1.85$ & 0.003 & 0.497 \\
DCHOT. \% & $68.45 \pm 1.68$ & $71.68 \pm 1.68$ & $68.63 \pm 1.68$ & $74.51 \pm 68$ & $69.43 \pm 1.68$ & 0.655 & 0.549 \\
DCHONF. $\%$ & $78.54 \pm 1.85$ & $83.49 \pm 1.85$ & $78.11 \pm 1.85$ & $83.71 \pm 1.85$ & $77.23 \pm 1.85$ & 0.831 & 0.378 \\
\hline
\end{tabular}

DMI - dry matter intake; DDM - dry matter apparent digestibility ; DCP - crude protein apparent digestibility; DEE - ether extract apparent digestibility; DNDF - neutral detergent fiber apparent digestibility $\left(\mathrm{Y}=52.1102+0.11742 \mathrm{CS}, \mathrm{R}^{2}=0.35\right)$; $\mathrm{DCHOT}-$ total carbohydrates apparent digestibility; DCHONF - non-fibrous carbohydrates apparent digestibility; 1 - probability for orthogonal contrasts: diets with $0 \%$ of soybean hull (0) versus diets with $100 \%$ of soybean hull in corn substitution and (L) linear ( 0 - 101$)$ and $(\mathrm{Q})$ quadratic $(0-12-1)$ effect of inclusion of soybean hulls in the diet, VC (variation coefficient).

According to Van Soest (1994), ruminal pH usually improves when the proportion of VFA produced in the rumen is altered by replacing cereal starch with fiber with higher digestibility. The present study did not confirm this theory, as the analysis of ruminal liquid $\mathrm{pH}$ showed that there was no effect of the replacement levels on this parameter. Therefore, the improvement in the apparent digestibility of NDF could be due to the physical characteristics of the pelleted soybean hull fiber (IPHARRAGUERRE; CLARK, 2003).

The results obtained in the present study are partially consistent with those described by Mendes et al. (2005), who evaluated the partial replacement of GC with SH or corn germ meal for confined steers fed $40 \%$ concentrate diets. The authors reported that the total apparent digestibility of $\mathrm{DM}, \mathrm{CB}$, NDF, and EE were not influenced by the different energy sources and presented mean values of 59.52, $54.70,44.90$ and $81.90 \%$, respectively. Grigsby et al. (1993) reported a higher NDF digestibility coefficient when $66 \%$ of the concentrate corn was replaced with $\mathrm{SH}$ in confined cattle feed. In a review by Ipharraguerre and Clark (2003), in situ and in vivo assay results demonstrated increased fermentation at higher rates of $\mathrm{SH}$ inclusionn the seven in situ experiments reviewed, the NDF of SH showed mean fermentation rates of 0.056 /hour. Four studies reviewed showed a disappearance rate 
of the NDF fraction that exceeded $90 \%$ after 96 hours of incubation. Mendes et al. (2010) evaluated the digestibility of nutrients from diets containing soybean or sugarcane bagasse as sources of NDF in the diet of lambs and found that the diets containing soybean hull had a higher digestibility of NDF (72\%).

Analysis of the variables related to ingestive behavior showed that there was no effect $(p>0.05)$ of the replacement levels on time spent feeding (F), with a mean value of $10.51 \%$ of the day. The variables standing idle (SI), lying idle (LI) and total idle (TI) were not influenced $(p>0.05)$ by the replacement levels, with mean values of 24.06, 46.83 and $4.61 \%$ of the day.

The variable standing rumination (RS) was not influenced by the replacement levels, with a mean value of $2.27 \%$ of the day. However, there was a quadratic effect $(\mathrm{P}<0.05)$ of the $\mathrm{SH}$ replacement levels on the time spent ruminating while lying down (RL) and total rumination (RT). There was a 3.88\% reduction in the total time spent ruminating when the replacement of GC with $\mathrm{SH}$ increased from 0 to $75 \%$, and a subsequent increase of $5.69 \%$ when the replacement increased from 75 to $100 \%$. There was a reduction of $2.09 \%$ in the time spent ruminating while lying down (RL) when the replacement of GC with $\mathrm{SH}$ increased from 0 to $75 \%$, and a subsequent increase of $6.25 \%$ when the replacement increased from 75 to $100 \%$, as demonstrated in Table 4 .
Several factors have a known effect on the time that confined cattle spend ruminating, such as the NDF content of the diet (MENDES et al., 2010), the particle size of the dietary ingredients (NEUMANN et al., 2009) and the level of consumption of DM (MIOTTO, 2014). In the present study, the increase in time spent ruminating when $\mathrm{SH}$ substitution increased from 75 to $100 \%$ could be attributed to the increase in NDF consumption given that there was no increase in dry matter consumption. This hypothesis is also supported by Mendes et al. (2010) who verified that the increase in the amount of NDF of the diet increased the intake of this component due to the increase in the amount of roughage in the diet, thus altering its effectiveness.

As reported by Mendes et al. (2010), the fiber source exerts an important influence on rumination activity in diets with high concentrate levels. However, according to Mertens (1997), the effectiveness of NDF is determined by the percentage of NDF in the food and the size of its particles, which must have a minimum size of 1.18 $\mathrm{mm}$ in order to stimulate rumination. Therefore, the physical form of SH used in the present study (pelleted) may also have promoted rumination effectiveness when $100 \%$ of the GC was replaced with $\mathrm{SH}$, since at this replacement level the pelleted SH comprised $74.07 \%$ of the total diet; however, the effect was not sufficient to improve ruminal $\mathrm{pH}$. 
Table 4. Means of ingestive behavior variables of confined cattle fed different levels of soybean husk (SH) in the diet.

\begin{tabular}{|c|c|c|c|c|c|c|c|c|c|}
\hline \multirow{2}{*}{ Activity } & \multicolumn{5}{|c|}{ Soybean hull levels, \% } & \multicolumn{4}{|c|}{ Contrasts $^{1}$} \\
\hline & 0 & 25 & 50 & 75 & 100 & $\mathrm{VC}, \%$ & $0 \mathrm{vs} \mathrm{SH}$ & $\mathrm{L}$ & $\mathrm{Q}$ \\
\hline $\mathrm{F}$, h/day & 2.45 & 2.63 & 2.60 & 2.50 & 2.43 & 26.91 & 0.721 & 0.880 & 0.673 \\
\hline F. \% day & 10.21 & 10.97 & 10.83 & 10.41 & 10.14 & 26.91 & 0.721 & 0.880 & 0.673 \\
\hline RS. ${ }^{h / d a y}$ & 0.95 & 0.35 & 0.53 & 0.52 & 0.38 & 42.89 & 0.051 & 0.309 & 0.361 \\
\hline RS. \% day & 3.96 & 1.46 & 2.22 & 2.15 & 1.60 & 42.89 & 0.051 & 0.310 & 0.361 \\
\hline RL. ${ }^{h / d a y}$ & 2.78 & 2.72 & 2.52 & 2.28 & 3.78 & 28.11 & 0.509 & 0.243 & 0.042 \\
\hline RL. \% day & 11.60 & 11.93 & 10.48 & 9.51 & 15.76 & 28.11 & 0.509 & 0.243 & 0.042 \\
\hline RT. ${ }^{\text {h/day }}$ & 3.73 & 3.07 & 3.05 & 2.80 & 4.17 & 24.72 & 0.102 & 0.688 & 0.025 \\
\hline RT. \% day & 15.55 & 12.78 & 12.71 & 11.67 & 17.36 & 24.72 & 0.102 & 0.688 & 0.025 \\
\hline SI. ${ }^{\text {h/day }}$ & 5.30 & 6.62 & 5.80 & 5.82 & 5.30 & 21.76 & 0.254 & 0.772 & 0.394 \\
\hline SI. \% day & 22.09 & 27.57 & 24.17 & 24.24 & 22.08 & 21.76 & 0.254 & 0.772 & 0.394 \\
\hline LI. ${ }^{h / d a y}$ & 11.05 & 11.05 & 11.58 & 11.70 & 10.82 & 18.73 & 0.723 & 0.966 & 0.671 \\
\hline LI. \% day & 46.04 & 46.04 & 48.26 & 48.75 & 45.07 & 18.73 & 0.723 & 0.966 & 0.671 \\
\hline TI. ${ }^{h / d a y}$ & 16.35 & 17.67 & 17.38 & 17.52 & 16.12 & 8.98 & 0.163 & 0.243 & 0.136 \\
\hline TI. \% day & 6.11 & 2.64 & 4.03 & 4.93 & 5.35 & 8.98 & 0.163 & 0.243 & 0.136 \\
\hline
\end{tabular}

$\mathrm{F}=$ feed; $\mathrm{RS}=$ standing rumination; $\mathrm{RL}=$ rumination lying down $\left(\mathrm{Y}, \mathrm{h} /\right.$ day $=2.946-0.029 \mathrm{CS}+0.00035 \mathrm{CS} 2, \mathrm{R}^{2}=0.25, \mathrm{Y}=\%$ day $\left.=12.275-0.1215 \mathrm{CS}+0.00148 \mathrm{CS}^{2}, \mathrm{R}^{2}=0.25\right) ; \mathrm{RT}=$ total rumination $\left(\mathrm{Y}, \mathrm{h} /\right.$ day $=3.79-0.0414 \mathrm{CS}+0.000438 \mathrm{CS}^{2}, \mathrm{R}^{2}=0.24 ;$ $\mathrm{Y}, \%$ day $\left.=15.795-0.11725 \mathrm{CS}+0.00183 \mathrm{CS}^{2}, \mathrm{R}^{2}=0.24\right) ; \mathrm{SI}=$ standing idle; $\mathrm{LI}=$ lying idle; $\mathrm{TI}=$ total idle; $\mathrm{SH}=\mathrm{soybean}$ hulls in the diet; 1 - probability for orthogonal contrasts: diets with $0 \%$ of soybean hull (0) versus diets with $100 \%$ of soybean hull in corn

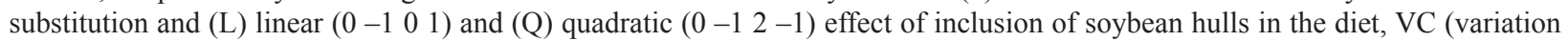
coefficient).

\section{Conclusions}

Although the replacement of corn with soybean hull does not improve the ruminal $\mathrm{pH}$ of steers fed diets with a high proportion of concentrate, the characteristics of pelleted soybean hulls provide greater digestibility of the fibrous fraction of the diet and a longer rumination time when total substitution occurs. These results reinforce the potential for using soybean hull as an alternative to corn as an energy source for confined cattle because it does not have negative implications for digestibility and ingestive behavior. However, other criteria with impacts on technical and economic efficiency must also be taken into consideration.

\section{References}

ASSOCIATION OF OFFICIAL ANALYTICAL CHEMISTRY - AOAC. Official methods of analysis. 16. ed. Washington: AOAC International, 1995.

CASALI, A. O.; DETMANN, E.; VALADARES FILHO, S. C.; PEREIRA, J. C.; HENRIQUES, L. T.; FREITAS, S. G.; PAULINO, M. F. Influência do tempo de incubação e do tamanho de partículas sobre os teores de compostos indigestíveis em alimentos e fezes bovinas obtidos por procedimentos in situ. Revista Brasileira de Zootecnia, Viçosa, v. 37, n. 02, p. 335-342, 2008.

COCHRAN, R. C.; ADAMS, D. C.; WALLACE, J. D. Predicting digestibility of different diets with internal markers: evaluation of four potential markers. Journal of Animal Science, Champaign, v. 63, n. 5, p. 1476-1483, 1986.

EZEQUIEL, J. M. B.; SILVA, O. G. C.; GALATI, R. L.; WATANABE, P. H.; BIAGIOLI, B.; FATURI, C. Desempenho de novilhos Nelore alimentados com casca de soja ou farelo de gérmen de milho em substituição parcial ao milho moído. Revista Brasileira de Zootecnia, Viçosa, v. 35, n. 02, p. 569-575, 2006. 
FISCHER, V.; MÜHLBACH, P. R. F. Substituição do grão de milho por casca de soja no desempenho de novilhas de corte confinadas. Pesquisa Agropecuária Gaúcha, Porto Alegre, v. 5, n. 1, p. 143-148, 1999.

FREITAS, L. S.; SILVA, J. H. S.; SEGABINAZZI, L. R.; ALVES FILHO, D. C.; PIZZUTI, L. A. D.; SILVA, V. S. and RODRIGUES, L. S. Performance of finishing steers fed different sources of carbohydrates. Revista Brasileira de Zootecnia, Viçosa, v. 42, n. 5, p. 354-362, 2013.

GRIGSBY, K. N.; KERLEY, M. S.; PATERSON, I. A. Combinations of starch and digestible fiberin supplements for steers consuming a low quality brome grass hay diet. Journal of Animal Science, Champaign, v. 71, n. 4, p. 1057-1064, 1993.

HALL, M. B. Neutral detergent-soluble carbohydrates: nutritional relevance and analysis, a laboratory manual. University of Florida, Gainesville, FL, USA, 2000. (Bulletin, 339).

HOOVER, W.H. Chemical factors involved in ruminal fiber digestion. Journal of Dairy Science, Illinois, v.69, n. 10, p.2755-2766, 1986.

IPHARRAGUERRE, I. R.; CLARK, J. H. Review: soy hulls for dairy cows. Journal of Dairy Science, Illinois, v. 86, n. 4, p. 1052-1073, 2003.

LUDDEN, P. A.; CECAVA, M. J.; HENDRIX, K. S. The value of soybean hulls as a replacement for corn in beef cattle diets formulated with or without added fat. Journal of Animal Science, Champaign, v. 73, n. 9, p. 2706-2711, 1995.

MENDES, A. R.; EZEQUIEL, J. M. B.; GALATI, R. L.; BOCCHI, A. L.; QUEIRÓZ, M. A. A.; FEITOSA, J. V. Consumo e digestibilidade total e parcial de dietas utilizando farelo de girassol e três fontes de energia em novilhos confinados. Revista Brasileira de Zootecnia, Viçosa, v. 34, n. 2, p. 679-691, 2005.

MENDES, C. Q.; TURINO, V. F.; SUSIN, I.; PIRES, A. V.; MORAIS, J. B.; GENTIL, R. G. Comportamento ingestivo de cordeiros e digestibilidade dos nutrientes de dietas contendo alta proporção de concentrado e diferentes fontes de fibra em detergente neutro. Revista Brasileira de Zootecnia, Viçosa, v. 39, n. 3, p. 594-600, 2010.

MERTENS, D. R. Creating a system for meeting the fiber requirements of dairy cows. Journal of Dairy Science, Illinois, v. 80, n. 7, p. 1463-1481, 1997.
MIOTTO, F. R. C.; NEIVA, J. N. M.; RESTLE, J.; FALCÃO, A. J. S.; CASTRO, K. J.; MACIEL, R. P. Comportamento ingestivo de tourinhos alimentados com dietas contendo níveis de gérmen de milho integral. Revista Ciência Animal Brasileira, Viçosa, v. 15, n. 1, p. 45-54, 2014.

NEUMANN, M.; RESTLE, J.; MÜHLBACH, P. R. F.; NÖRNBERG, J. L.; ROMANO, M. A.; LUSTOSA, S. B. C. Comportamento ingestivo e de atividades de novilhos confinados com silagens de milho de diferentes tamanhos de partícula e alturas de colheita. Ciência Animal Brasileira, Goiânia, v. 10, n. 2, p. 462-473, 2009.

NGUYEN, T. V.; LOUIS, S. T. D. G.; ORR, A. I.; RUDE, B. J. Supplementing maize or soybean hulls to cattle fed rice straw: intake, apparent digestion, in situ disappearance and ruminal dynamics. Asian-Australian Journal Animal Science, Seoul, v. 21, n. 6, p. 807-817, 2008.

ORR, A. I.; HENLEY, J. C.; RUDE, B. J. The substitution of corn with soybean hulls and subsequent impact on digestibility of a forage-based diet offered to beef cattle. The Professional Animal Scientist, London, v. 24, n. 6, p. 566-571, 2008.

RESTLE, J.; FATURI, C.; ALVES, F. D. C.; BRONDANI, I. L.; SILVA, J. H. S. da.; KUSS, F. Substituição do grão de sorgo por casca de soja na dieta de novilhos terminados em confinamento. Revista Brasileira de Zootecnia, Viçosa, v. 33, n. 4, p. 1009-1015, 2004.

STATISTICAL ANALYSIS SYSTEM INSTITUTE SAS/STAT user's guide: statistics. 6. ed. Version 8. Cary, NC, 2002. v. 2, 943 p.

TAMMINGA, S.; VAN VUUREN, A. M. Formation and utilization of end products of lignocellulose degradation in ruminants. Animal Feed Science and Technology, Amesterdã, v. 21, n. 2-4, p. 141-159, 1988.

VAN SOEST, P. J. Nutritional ecology of the ruminant. 2. ed. Ithaca: Cornell University Press, 1994. 476 p.

VAN SOEST, P. J.; ROBERTSON, J. B.; LEWIS, B. A. Methods for dietary fiber, neutral detergent fiber, and nonstarch polysaccharides in relation to animal nutrition. Journal of Animal Science, Champaign, v. 74, n. 10, p. 3583-3597, 1991.

WING, J. M. Citrus feedstuffs for dairy cattle. Gainsville: University of Florida, Agricultural Experiment Station, 1982. 25 p. 
